\author{
EVS24 \\ Stavanger, Norway, May 13-16, 2009
}

\title{
Monitoring and Simulation of Fuel Cell Electric Vehicles
}

\author{
Gonçalves, G. A., Bravo, J. T, Baptista P. C., Silva C. M. and Farias T.L. \\ ${ }^{1}$ IDMEC \\ Av. Rovisco Pais, 1049-001 Lisboa, Portugal \\ goncalo.goncalves@ist.utl.pt
}

\begin{abstract}
The objective of this research is to develop a fuel cell hydrogen vehicle model (FC-RVS) and validate it with existing black-box models and with real on-board data. On-board data for dynamic profile, topography and fuel consumption was collected in the city of Porto in the framework of the hydrogen bus demonstration project CUTE (Clean Urban Transport for Europe). The vehicle used is part of a fleet of 27 urban buses developed and built by Evobus and uses a fuel cell based non-hybrid propulsion system. The data collected in Porto reflects a very demanding drive cycle that resulted in the availability of data for several operating conditions. The fuel cell vehicle is modelled by using efficiency maps of each powertrain component. Trough a backward approach the power requested is transformed in hydrogen consumption. Finally, optimized configurations to achieve the lowest hydrogen consumption possible are analyzed, including hybridization. FC-RVS model predictions were within $4 \%$ of measured results.
\end{abstract}

Keywords: Hydrogen, fuel cell, demonstration, modeling

\section{Introduction}

The road transport sector has a high fossil fuel dependency. The urge for energy security of supply, air quality improvement in urban areas and $\mathrm{CO}_{2}$ emissions reduction are pressing decision makers/manufacturers to act on the road transportation sector, introducing more efficient vehicles on the market and diversifying the energy sources. Accordingly, hydrogen propulsion is being considered. The main barrier to the widespread of the fuel among private vehicle owners is the refueling infrastructure. For this reason, the majority of demonstration projects are related to the public transport sector, such as the Clean Urban Transport for Europe (CUTE), and the follow-up, HyFLEET:CUTE, the Sustainable Transport Energy Programme (STEP) and the Ecological City Transport System (ECTOS) [1].
The aim of the present paper is to present experimental data obtained from the European project CUTE and a model suitable to simulate hydrogen bus consumption according to different drive cycles, driver behavior and occupancy rates.

\subsection{Model literature review}

The Road Vehicle Simulation (RVS) model translates dynamic profile, topography and vehicle load into powertrain power behavior like engine rpm and load, and then calculates fuel consumption and emissions based on fuel converter maps. These maps, although not mandatory for certification are measured by most manufacturers (although usually not made public) using test bench testing. The resulting maps provide specific emissions of pollutants and fuel consumption (typically in $\mathrm{g} / \mathrm{s}$ or $\mathrm{g} / \mathrm{kWh}$ ). Some models that use this approach for modeling are 


\section{EcoGest [2] [3], ADVISOR [4] [5] and PSAT [6] [7].}

EcoGest is a simulation model for fuel consumption and pollutant emissions for spark ignition road vehicles [2] [3]. It has the possibility to analyze real driving cycles, considering the vehicle characteristics like weight, transmission and exhaust after-treatment. The model also takes into consideration the topography and load. The model can also use any measured parameters from an on-board monitoring system: speed, grade, fuel consumption and number of passengers and has a database with several engine maps for specific fuel consumption and pollutant emission $(\mathrm{HC}$, $\mathrm{CO}$ and $\mathrm{NO}_{\mathrm{x}}$ ), for stationary, warm operating conditions. These maps are either supplied by engine manufacturers or generated by a submodel for conventional and alternative fuels. The internal calculations of the EcoGest model are based on the determination of engine load and rpm at each moment according to vehicle speed and gearbox management. One sub-model deals with exhaust after-treatment for vehicles equipped with catalytic converters and computes the emissions to the atmosphere. This type of models are limited in the sense that they are based on an emission map for a new engine and do not take into consideration ageing (of the engine, not the catalytic converter) and by using stationary emission maps that do not take into consideration transient operating conditions.

ADVISOR [4] [5] is a model originally developed by NREL (National Renewable Energy Laboratory), for the US DOE. It is a tool that can be used to evaluate and quantify the vehicle level impacts of advanced technologies applied to vehicles. It is written in the MATLAB/Simulink environment and was until recently freely distributed via the Internet (now commercialized by AVL). ADVISOR is primarily used to quantify the fuel economy, performance, and emissions of vehicles that use alternative technologies, specifically HEV architectures. It employs a unique combined backward/forward-facing modeling approach. This approach allows ADVISOR to accurately represent vehicle operation under a multitude of operating scenarios without the need to iterate, as other models must. When detailed component models are necessary, the open and modular design of ADVISOR makes the connection to detailed, dynamic, and proprietary models possible. ADVISOR currently includes multiple fuel cell models and battery models of varying degrees of complexity.

PSAT (Powertrain Systems Analysis Toolkit) [6] [7] was developed at the Argonne National Laboratory and allows dynamic analysis of vehicle performance and efficiency to support detailed design, hardware development, and validation. Only fuel consumption is estimated. A driver model attempts to follow a vehicle driving cycle, sending a power demand to the vehicle controller which, in turn, sends a demand to the propulsion components (commonly referred to as "forwardfacing" simulation). Dynamic component models react to the demand (using transient equationbased and physics-based models).

RVS is a result of EcoGest upgrade and is similar to ADVISOR and PSAT although allows to simulate all types of alternative fuels (biodiesel, ethanol, natural gas, hydrogen, LPG), including engine fuel consumption and emissions map generation. It includes other options such as varying auxiliary power as a function of time. The main input variables are commonly available. It is possible to program new powertrain configurations and strategies.

\section{CUTE project description}

The aim of the CUTE (Clean Urban Transport for Europe) project was to develop and demonstrate an emission-free and low-noise transport system, including the accompanying energy infrastructure, with three main targets:

- Improve the quality of the atmosphere and life in densely populated areas

- Diversification of energy sources and conservation of fossil resources

- Identify the potential for reducing the global greenhouse effect towards the Kyoto protocol

For this purpose, 27 hydrogen fuelled fuel-cell buses were tested for 2 years in 9 European cities. In each city the supporting infrastructure was built and operated by energy suppliers and urban bus operators. This project had the financial support from the European Community and was at the time (and continued with the project HyFLEET:CUTE that succeeded it [8]) the largest project worldwide in fuel cell technology demonstration in transports.

\subsection{Hydrogen bus description}

The vehicle used in the project was based on the standard Diesel powered Citaro bus 
commercialized by EvoBus (a subsidiary of the Daimler group).

The engine and transmission are located in the same position than that of a conventional Diesel bus and the vehicle offers the same passenger space. In order to increase the reliability of the vehicle, the changes were been reduced to a minimum, keeping as much of the conventional bus parts as possible.

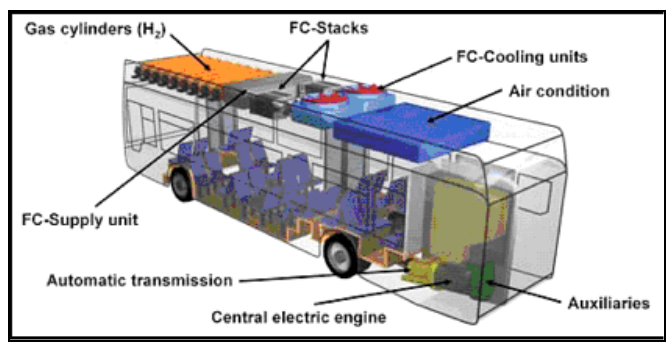

Figure 1: Layout of main elements

The entire fuel cell system is located on the roof of the bus (Figure 1). This required some changes in the suspension and chassis in order to cope with the extra weight in a high location. This was decided based on several considerations:

- Safety in terms of accidents, as the rooftop of the bus is rarely damaged in the case of a collision;

- In the case of leakage, the hydrogen is immediately vented to the atmosphere;

- The location provides easy access for maintenance.

The hydrogen is stored on board in compressed form at a pressure of $350 \mathrm{bar}$. The storage module uses 9 cylinders (carbon fiber wrapped aluminum liner), each with a volume of 205 liters. The total storage capacity (at the nominal pressure of $350 \mathrm{bar}$ ) is $44 \mathrm{~kg}$ of hydrogen, sufficient to fulfill the typical daily range requirements for city buses.

The fuel cell is of the PEM type, and the two stacks are capable of providing a total gross power of $250 \mathrm{~kW}$. The DC current produced is converted into $\mathrm{AC}$ in an inverter before being fed to the main electric engine. In order to ensure the simplicity of the system, all other electrical components are supplied from the main engine.

The electrical traction engine is placed in the same position as in a conventional bus. It is designed to a maximum power of $205 \mathrm{~kW}$, comparable to the power of conventional diesel and natural gas city buses.

The rear axle and automatic transmission are similar to the ones used in the conventional Citaro model; the changes are essentially in the gearbox gear ratios, which have been adapted for the specific characteristics of the engine. The presence of the gearbox ensured an easier adaptation of the drivers.

\subsection{Hydrogen bus monitoring}

The monitoring of the buses follows two strategies. First a comprehensive monitoring plan was setup in each city to collect the daily operation data. This allowed comparing different operating conditions (climate, topography, traffic), one of the main objectives of the project (Figure 2).

Figure 2: Comparison of average speed and fuel consumption in the cities of the CUTE project

Secondly, to complement the monitoring program, in selected cities a detailed monitoring was performed during a limited number of days. The hydrogen fuel cell bus has its own dedicated data collecting and logging system, and the data used for this analysis (namely speed profile and fuel consumption) was supplied by Evobus in the framework of the CUTE project. The logging frequency was $2 \mathrm{~Hz}$. The topography profile was obtained using a dedicated monitoring system onboard a Diesel bus on the same route. Manual passenger counts were performed on-board the vehicle.

The route for the operation of the buses in Porto where the measurements presented were made was selected according to the objectives of the project for demanding service (high gradients, heavy traffic and low average speed) and good visibility to the population. It's a circular line with the same start and stop point (Figure 3) that serves the inner center of the city of Porto. The vehicles measured circulated clockwise, the starting point being Praça da Liberdade. Total length was 7800 meters. 


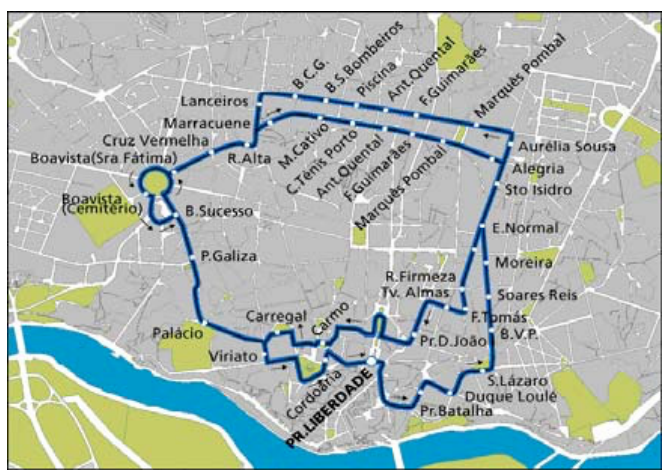

Figure 3: Route operated by the test buses

The topography profile is very demanding, as can be seen in Figure 4. The altitudes presented are not absolute but relative to the lowest point on the route.

\section{RVS model}

The Road Vehicle Simulation (RVS) model is able to simulate conventional powertrain fuel consumption and emissions. Concerning advanced powertrains it is able to simulate electrical consumption of pure battery-electric vehicles and hybrid plug-in vehicles and hydrogen consumption of fuel cell vehicles. The description of the fuel cell vehicles model (FC-RVS) is described below.

\subsection{Introduction}

In a fuel cell electric vehicle (FCEV) the fuel cell is connected to an electric motor using an electric inverter/converter. The electric motor(s) can be connected directly to the wheels or connected trough a differential or/and gear boxes (Figure 5). It can also have mechanical accessories connected to the electric motor and electric accessories connected to the fuel cell.

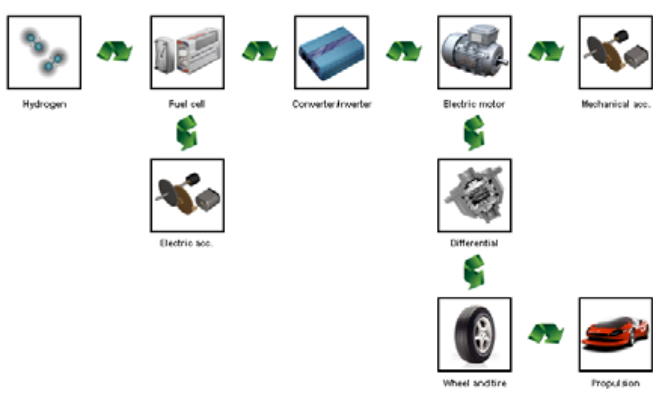

Figure 5: Flow of power for fuel cell electric vehicle configuration

\subsection{FC-RVS simulation model}

RVS simulates fuel cell vehicles starting with:

- longitudinal vehicle dynamics;

- powertrain modeling including fuel cell, converter/inverter, electric motor, differential and wheel including all accessories.

\subsubsection{Longitudinal vehicle dynamics}

The propulsion system produces mechanical energy that is stored in the form of kinetic and potential energy. There are also driving resistances that drain energy from this reservoir: aerodynamic, rolling and braking friction [9].

The elementary equation that describes the longitudinal dynamics is:

$$
\begin{aligned}
& P_{t}=F_{t} \dot{x}(t)=\left(F_{i}+F_{a}+F_{r}+F_{g}\right) \dot{x}(t) \\
& F_{i}=\left(m_{\text {veh }} k_{m}+m_{\text {carg } o}\right) \ddot{x}(t) \dot{x}(t)
\end{aligned}
$$

In total, about 8 hours of data were collected at 2 RVS model 


$$
\begin{aligned}
& F_{a}=\frac{1}{2} \rho_{a} A_{f} c_{d} \dot{x}(t)^{2} \\
& F_{r}=c_{r}\left(m_{\text {veh }}+m_{\text {cargo } o}\right) g \cos (\alpha) \\
& F_{g}=\left(m_{\text {veh }}+m_{\text {cargo } o}\right) g \sin (\alpha)
\end{aligned}
$$

Where $P_{t}$ and $F_{t}$ are propulsion power and force, $F_{i}$ is the inertial force, $F_{a}$ is aerodynamic friction, $F_{r}$ is rolling friction and $F_{g}$ is gravity effect. $x(t)$ refers to vehicle position function of time (see Figure 6). $m_{v e h}$ refers to vehicle curb weight, $m_{\text {cargo }}$ refers to cargo weight and $k_{m}$ to equivalent mass increase due to rotational components. $\rho_{a}$ is the air density, $A_{f}$ is the vehicle frontal area, $c_{d}$ is the aerodynamic drag coefficient and finally $c_{r}$ is the rolling friction coefficient.

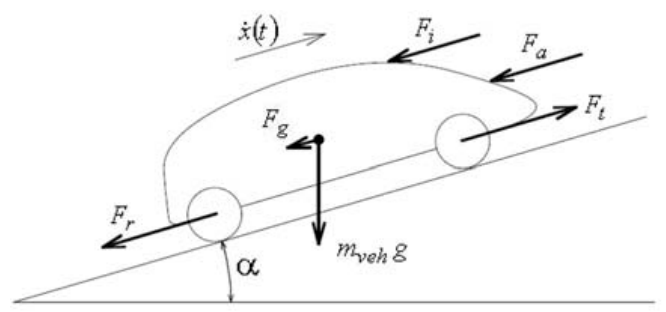

Figure 6: Schematic representation of the forces acting on vehicle during motion

\subsubsection{Fuel cell}

For this component the approach was to use a map having fuel consumption $\left(\dot{m}_{H}\right)$ as a function of fuel cell (FC) output electric power $\left(P_{F C}\right)$. FC efficiency $\left(\eta_{F C}\right)$ can be calculated by [10]:

$\eta_{F C}=\frac{P_{F C}}{\dot{m}_{H} L H V_{H}}$

Where $L H V_{H}$ is the hydrogen lower heating value. The FC response capability to transient power variations $\left(\frac{d P_{F C}}{d t}\right)$ is usually limited [10]. In this model power increase rate was limited by a constant value $\left(\dot{P}_{F C \max }\right)$. This value is case dependent and is assumed to be $4000 \mathrm{~W} / \mathrm{s}$ for a $100 \mathrm{~kW}$ fuel cell.

$\frac{d P_{F C}}{d t} \leq \dot{P}_{F C \max }$

Power dump is the minimum FC electric power associated with minimum FC current, resulting in the FC having always a minimum hydrogen consumption. This feature is associated to FC life expectancy.

\subsubsection{Electric Inverter/Converter}

This device is usually a very efficient one (efficiency of $90 \%$ to $99 \%$ [11]) and the approach was simplified to a constant efficiency $\left(\eta_{E I C}\right)$ model:

$P_{\text {EICout }}=\eta_{\text {EIC }} P_{\text {EICin }}$

Where $P_{\text {EICout }}$ is the power exiting and $P_{\text {EICin }}$ is power entering the electronic device.

It is important to refer that usually this efficiency is already included in the electric motor/generator data or model because experimental data measurement is easier to obtain when it is included.

\subsubsection{Electric motor}

For the electric motor (EM) component the approach [11] was to use a map having the electric motor efficiency $\left(\eta_{E M}\right)$ as a function of the electric motor speed $\left(\omega_{E M}\right)$ and load $\left(L_{E M}\right)$ :

$L_{E M}=\frac{T_{E M}\left(\omega_{E M}\right)}{T_{E M \max }\left(\omega_{E M}\right)}$

Where $T_{E M}$ refers to EM torque. It is important to account EM moment of inertia (including also wheels and all rotating parts). If it is unknown it is usual practice to increase a certain percentage of vehicle mass, usually around $5 \%\left(k_{m}=1.05\right)$.

It is common for EM to have the possibility, for short periods of time, to increase maximum torque beyond the nominal value, this characteristic is called the overtorque (OT). When the EM is working above nominal power its temperature will begin to increase rapidly so this feature cannot be continuous, because the motor would overheat and this would limit the EM life expectancy. In this model the time which the vehicle can maintain overtorque is considered to be infinite which in most of the cases is not a problem because this type of utilization is required for short time intervals, such as when vehicle is accelerating. In overtorque situation the considered efficiency is the same has at maximum nominal value. Overtorque is given by:

$O T=\frac{T_{E M \text { transient }}}{T_{E M \text { continous }}}$ 
Where $T_{E M \text { transient }}$ is the maximum transient torque and $T_{E M \text { continous }}$ is the maximum continuous torque (without overheating).

\subsubsection{Accessories}

The electric accessories include all electric vehicle accessories and are supplied from FC power and are usually a function of time. The mechanical accessories are linked to the EM. In some situations they are considered to be constant either for simplicity or because it is an unknown variable in time.

\subsection{Model input}

The simulation input used was extracted from experimental results obtained from the project Clean Urban Transport for Europe CUTE [12]. Table 2 shows the vehicle characteristics used in the model.

Table 2: Vehicle characteristics

\begin{tabular}{|c|c|c|}
\hline & & FC-RVS \\
\hline \multirow{2}{*}{ Environment } & Frontal wind $[\mathrm{m} / \mathbf{s}]$ & 0 \\
\hline & Air density $\left[\mathrm{kg} / \mathrm{m}^{3}\right]$ & 1.23 \\
\hline \multirow{10}{*}{ Vehicle } & $\begin{array}{c}\text { Mass [kg] } \\
\text { (including cargo) }\end{array}$ & 16000 \\
\hline & $k_{m}$ & 1.05 \\
\hline & $\begin{array}{c}\text { Coefficient of rolling resist. } \\
\left(c_{r}\right)\end{array}$ & 0.011 \\
\hline & Transmission efficiency & $97 \%$ \\
\hline & Frontal area $\left(A_{f}\right)\left[\mathrm{m}^{2}\right]$ & 8.46 \\
\hline & Drag coefficient $\left(c_{d}\right)$ & 0.72 \\
\hline & Tire size & $\begin{array}{l}295 / 60 \\
\mathrm{R} 22.5 \\
\end{array}$ \\
\hline & Radius [m] & 0.427 \\
\hline & Mechanical auxiliaries [W] & 17000 \\
\hline & Electric auxilaries [W] & 0 \\
\hline \multirow[t]{2}{*}{$\begin{array}{l}\text { Electric } \\
\text { Motor }\end{array}$} & $\begin{array}{c}\text { Maximum power of the AC } \\
\text { (Alternated Current) } \\
\text { induction electric motor }\end{array}$ & $205 \mathrm{~kW}$ \\
\hline & Overtorque & 1.8 \\
\hline \multirow{2}{*}{ Fuel Cell } & $\begin{array}{c}\text { 2x PEM (Polymer } \\
\text { Electrolyte Membrane) } \\
\end{array}$ & $250 \mathrm{~kW}$ \\
\hline & Power Dump & $30 \mathrm{~kW}$ \\
\hline $\begin{array}{c}\text { Driving } \\
\text { Cycle }\end{array}$ & $\begin{array}{l}\text { CUTE driving cycle from } \\
\text { Porto (see Figure 7) }\end{array}$ & $\begin{array}{l}0.5 \text { s time } \\
\text { step }\end{array}$ \\
\hline
\end{tabular}

Figure 3 shows one of the measured driving profiles of the bus running in Porto city.

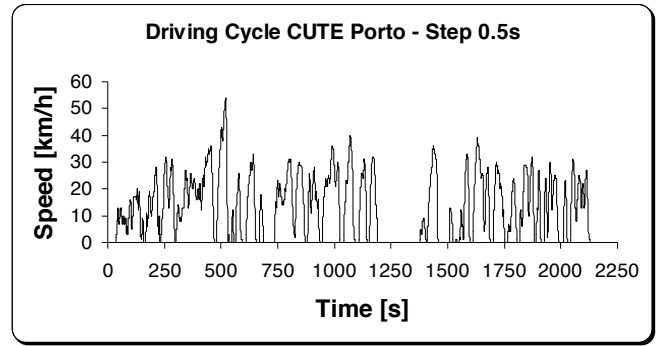

Figure 7: Driving cycle chart used in simulation

\subsubsection{Fuel cell}

FC hydrogen consumption as a function of power output experimental results of the bus are presented in Figure 8 [12]:

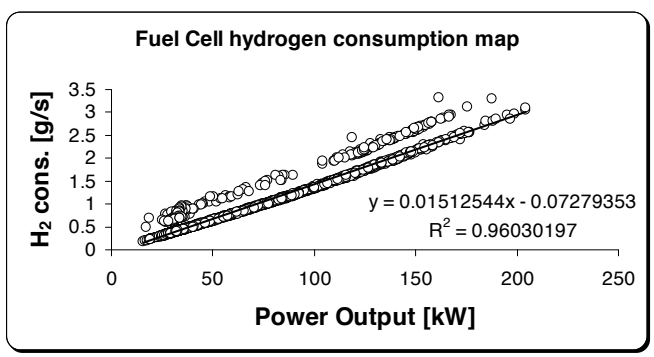

Figure 8: FC experimental data

The FC output power did not account auxiliaries power lost so in this case this is accounted in the electrochemical FC efficiency. Purge is responsible for $8 \%$ of the points outside the main fit curve. It was possible to extract two averaged FC fuel consumption and FC efficiency curves used to simulate the CUTE bus (Figure 9):



Figure 9: FC fuel consumption and efficiency used in the model 


\subsubsection{Electric motor}

Usually the manufacturers do not give efficiency information with EM torque or power and efficiency as a function of EM speed. Also OT data may not be available. In this case the hydrogen bus EM information was not available so an ADVISOR map (Figure 10) was scaled accordingly (inverter already included) to meet maximum performance $(205 \mathrm{~kW})$.

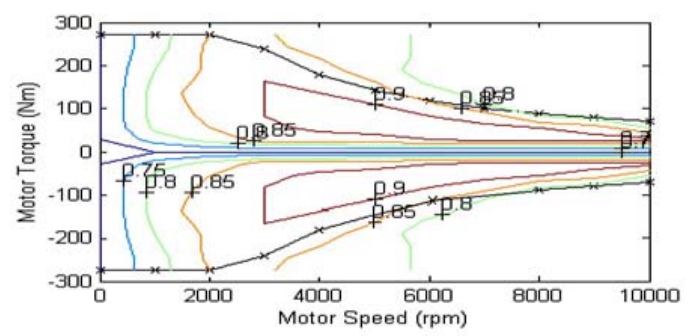

Figure 10: Westinghouse $75 \mathrm{~kW}$ from ADVISOR

\subsection{Model versus experimental bus data}

The bus monitored data in Porto was used to validate FC-RVS model and also to compare with ADVISOR. The results obtained for hydrogen consumption (Table 3) (Figure 11) are in good agreement with simulation results.

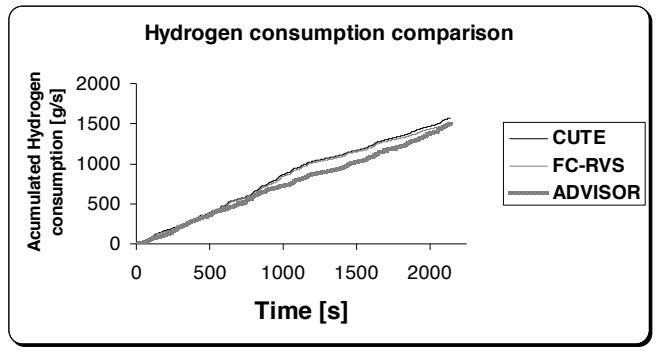

Figure 11: Comparison between experimental (CUTE), ADVISOR and FC-RVS

Table 3: Comparison results between experimental data and used models

\begin{tabular}{|c|c|c|c|}
\hline & CUTE & RVS & ADVISOR \\
\hline $\begin{array}{c}\text { Hydrogen } \\
\text { Cons. [g] }\end{array}$ & 1567.95 & 1518.08 & 1500.84 \\
\hline Error & ------------ & $-3.18 \%$ & $-4.28 \%$ \\
\hline
\end{tabular}

\section{Conclusions}

A simulation of fuel cell road vehicles has been built with the aim to simulate hydrogen consumption. The results of the simulation were within $4 \%$ when compared with experimental ones. ADVISOR showed higher discrepancy when compared with FC-RVS because it converts the 0.5 second time step driving cycle into 1 second time step.

\section{Acknowledgments}

The authors would like to acknowledge FCTFundação para a Ciência e Tecnologia (National Science and Technology Foundation) through the national project MMSAFU-Microssimulation Model to Simulate Alternative Fuel Usage (POCI/ENR/57450/2004), national project Power demand estimation and power system impacts resulting of fleet penetration of electric/plug-in vehicles (MIT-Pt/SES-GI/0008/2008) and through the PHD grants (SFRH/BD/27736/2006 and SFRH/BD/35191/2007).

\section{References}

[1] J. Ally., T.P., Life-Cycle assessment of diesel, natural gas and hydrogen fuel cell bus transportation systems. Journal of Power Sources, 2007. 170: p. 401-411.

[2] Silva, C.M., Farias, T.L., Frey, H.C., Rouphail, N.M., 2006. Evaluation of numerical models for simulation of real-world hot-stabilized fuel consumption and emissions of gasoline light-duty vehicles. Transportation Research Part D 11, 377385 .

[3] Silva CM, Goncalves GA, Farias TL, MendesLopes JMC. A tank-to-wheel analysis tool for energy and emissions studies in road vehicles. SCIENCE OF THE TOTAL ENVIRONMENT Volume: 367 Issue: 1 Pages: 441-447 2006.

[4] http://www.avl.com/wo/webobsession.servlet. go?app $=$ bcms\&page $=$ view\&nodeid $=400030459$ (Last access November 2008)

[5] T. Markel, A. Brooker, T. Hendricks, V. Johnson, K. Kelly, B. Kramer, M. O'Keefe, S. Sprik and K. Wipke, ADVISOR: a systems analysis tool for advanced vehicle modeling, Volume 110, Issue 2, 22 August 2002, Pages 255-266

[6] http://www.transportation.anl.gov/modeling_si mulation/PSAT/index.html (Last access November 2008) 
[7] FreedomCAR and Fuel Partnership, Vehicle Systems Analysis Technical Team, September 2006

[8] Gonçalves, G.A., Portugal, J.O., Farias, T.L. Life Cycle Assessment Of Hydrogen Production And Vehicle Operation In A Municipal Bus Fleet The Berlin Application, Transportation Land Use, Planning, and Air Quality, Orlando, Florida, July 9-11, 2007

[9] Guzzela, L. and Sciarretta, A. "Vehicle Propulsion Systems", Springer 2007

[10] Hoogers, G. "Fuel Cell Technology Handbook", CRC Press, 2003

[11] Larminie, J. and Lowry, J. "Electric Vehicle Technology Explained". Wiley, 2003

[12] Saxe, M., Folkesson, A. and Alvfors, P. Energy system analysis of the fuel cell buses operated in the project: Clean Urban Transport for Europe. Energy, vol.33, pg. 689-711, 2008.

\section{Authors}

\begin{tabular}{|l|l|} 
Gonçalo A. Gonçalves received a \\
degree in Mechanical Engineering in \\
2001 and a PhD degree in Mechanical \\
Engineering in 2009 at Instituto \\
Superior Técnico, Technical \\
University of Lisbon in Portugal. \\
He currently coordinates the \\
Transport, Energy and Emissions \\
laboratory. \\
Areas of interest include evaluation of \\
conventional and alternative \\
propulsion systems and fuels, vehicle \\
monitoring and evaluation of driver \\
behavior.
\end{tabular}

\begin{tabular}{|l|l|}
\hline & $\begin{array}{l}\text { alternative vehicle technologies and } \\
\text { energy sources on the Portuguese road } \\
\text { transportation sector. } \\
\text { Carla M. Silva received the } \\
\text { Mechanical Engineering degree (five- } \\
\text { year course) in 2000 and the PhD } \\
\text { degree in Mechanical Engineering in } \\
\text { 2005, both at Instituto Superior } \\
\text { Técnico, Technical University of } \\
\text { Lisbon, Lisboa Portugal. She went for } \\
\text { a post doc at both IST and University } \\
\text { of Michigan working on CO2 } \\
\text { mitigation in road vehicles. Currently } \\
\text { she is a research assistant at IDMEC- } \\
\text { Institute of Mechanical Engineering at } \\
\text { IST. Areas of interest are new } \\
\text { technologies and alternative fuel } \\
\text { vehicles simulation; life-cycle analysis } \\
\text { and projections } \\
\text { Tiago Alexandre Abranches Teixeira } \\
\text { Lopes Farias received the mechanical } \\
\text { engineering degree and the Ph.D. } \\
\text { degree in mechanical engineering from } \\
\text { the Technical University of Lisbon, } \\
\text { Instituto Superior Técnico, Portugal, in } \\
\text { 1990 and 1997, respectively. In 2008, } \\
\text { he received the Aggregation degree } \\
\text { from the Technical University of } \\
\text { Lisbon. Currently, he is an Assistant } \\
\text { Professor in the Department of } \\
\text { Mechanical Engineering of the Faculty } \\
\text { of Instituto Superior Técnico. He is } \\
\text { also Coordinator of the Research team } \\
\text { of Transports, Energy and } \\
\text { Environment of Instituto de } \\
\text { Engenharia Mecânica - IDMEC. }\end{array}$ \\
\hline
\end{tabular}

